\title{
New Product Development; The Nikola Tesla Extrapolation
}

\author{
Martínez-Escobedo, Eduardo
}

PhD candidate - Universitat Politècnica de València, España. eduardo.martinez@udem.edu

\section{Resumen}

El desarrollo de productos se ha abordado mediante métodos lineales que se aplican a cualquier problema de diseño sin importar las variables ambientales. En este enfoque, encontraremos un nuevo método de matriz que puede ofrecer una ruta básica en la que el diseñador puede comenzar su viaje, pero adaptable para aceptar variables ambientales. Nikola Tesla en su libro "La extraña vida de Nikola Tesla" (1914) nos dijo: "Así me han llevado inconscientemente a desarrollar lo que considero un nuevo método de materializar conceptos e ideas inventivas, que es radialmente opuesto a lo puramente experimental y es, en mi opinión, mucho más expeditivo y eficiente. En el momento en que uno construye un dispositivo para llevar a la práctica una idea cruda, se encuentra inevitablemente absorto con los detalles del aparato. A medida que mejora y reconstruye, su fuerza de concentración disminuye, y pierde de vista el gran principio subyacente. Los resultados pueden ser obtenidos, pero siempre en el sacrificio de la calidad. Mi método es diferente. No me apresuro al trabajo real. Cuando tengo una idea, comienzo a construirla en mi imaginación. Cambio la construcción, hago mejoras y manejo el dispositivo en mi mente. Para mí no tiene importancia si uso mi turbina o la pruebo en mi tienda. Incluso noto si está fuera de balance. No hay diferencia alguna; Los resultados son los mismos. De esta manera, puedo desarrollar y perfeccionar rápidamente una concepción sin tocar nada. Cuando he ido tan lejos como para incorporar en la invención todas las mejoras posibles en las que puedo pensar y no veo ninguna falla en ninguna parte, puse en forma concreta este producto final de mi cerebro. Invariablemente mi dispositivo funciona como lo concebí, y el experimento sale exactamente como lo planeé. En veinte años, no ha habido una sola excepción. ¿Por qué debería ser de otra manera? Ingeniería, eléctrica y mecánica, es positiva en los resultados. Apenas hay un tema que no pueda examinarse previamente, a partir de 
los datos teóricos y prácticos disponibles". El enfoque de diseño de Tesla nos dice que basamos la energía creativa en el diseño conceptual. Para que un diseñador obtenga los mejores resultados, el método sugiere tres pasos: preparación, exploración y diseño conceptual. En preparación, el diseñador debe abrir su mente y aprender a manejar su músculo creativo, la exploración lo guiará por el camino del conocimiento a través de la ciencia y la tecnología, y cuando tenga todas las herramientas a mano comenzará el diseño conceptual. Una vez que se adquiere un diseño conceptual con los detalles sugeridos por Tesla, casi cualquier persona con habilidades de modelado puede hacer el diseño detallado.

Palabras clave: diseño, método, Nikola, Tesla, extrapolación.

\section{Abstract}

Product development has been approached by linear methods that apply to any design problem without concern of ambient variables. In this approach, we will find a new matrix method that can deliver a basic path in which the designer can begin his journey, but adaptable to accept ambient variables.

Nikola Tesla in his book "The Strange Life of Nikola Tesla" (1914) told us: "Thus I have been led unconsciously to evolve what I consider a new method of materializing inventive concepts and ideas, which is radially opposite to the purely experimental and is in my opinion ever so much more expeditious and efficient. The moment one constructs a device to carry into practice a crude idea, he finds himself unavoidably engrossed with the details of the apparatus. As he goes on improving and reconstructing, his force of concentration diminishes, and he loses sight of the great underlying principle. Results may be obtained, but always at the sacrifice of quality. My method is different. I do not rush into actual work. When I get an idea, I start at once building it up in my imagination. I change the construction, make improvements, and operate the device in my mind. It is immaterial to me whether I run my turbine in thought or test it in my shop. I even note if it is out of balance. There is no difference whatever; the results are the same. In this way, I can rapidly develop and perfect a conception without touching anything. When I have gone as far as to embody in the invention every possible improvement I can think of and see no fault anywhere, I put into concrete form this final product of my brain. Invariably my device works as I 
conceived that it should, and the experiment comes out exactly as I planned it. In twenty years, there has not been a single exception. Why should it be otherwise? Engineering, electrical and mechanical, is positive in results. There is scarcely a subject that cannot be examined beforehand, from the available theoretical and practical data." Tesla's approach to design tells us to base the creative energy in the conceptual design. For a designer to get the best results, the method suggests three steps: Preparation, Exploration, and Conceptual Design. In preparation, the designer must open his mind and learn how to handle his creative muscle, exploration will guide him thru the path of knowledge thru science, and technology, and when he has all the tools on hand will begin the conceptual design. Once a conceptual design is acquired with the details Tesla suggested, nearly anyone with modeling skills can make the detailed design.

Keywords: Design, Method, Nikola, Tesla, Extrapolation

\section{Introduction}

New Product Development; The Nikola Tesla Extrapolation (Martinez, 2017), is a method for developing new products. Merriam-Webster defines product as something resulting from or necessarily following from a set of conditions. This definition does not limit our scope to physical devices, but can be used thru a variety of solutions varying from electrical to service design.

The method consists of three main phases as shown in Figure 1: 


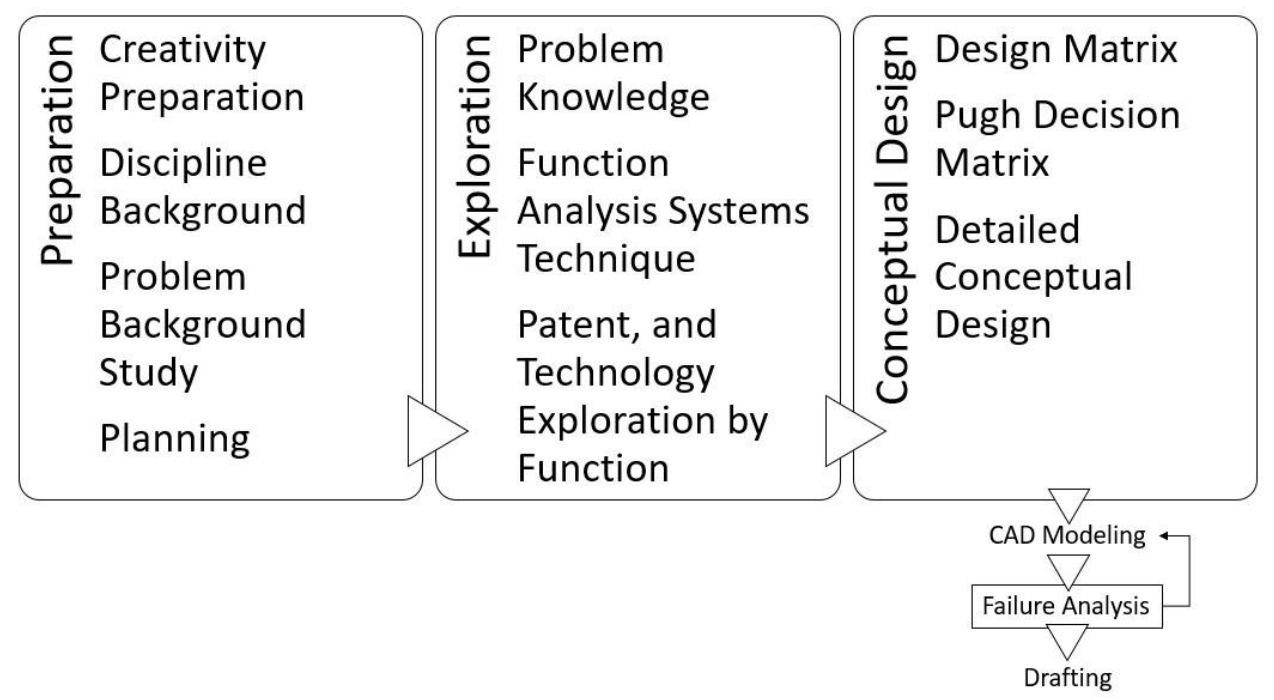

Fig. 1 New Product Development; NT Extrapolation matrix

The output obtained is a conceptual design as complete as possible, due to the knowledge that the biggest waste of time, during a product development, is derived from uncertainty (Wynn, Grebici \& Clarkson, 2011). This justifies the need to have a conceptual design that removes as much uncertainty from the process as possible.

\subsection{Preparation Phase}

Preparation is the first phase for this method, and maybe it can be considered as the most important phase. The role of science in design is to provide tools for the designer to practice their art, but idea generation is the most difficult of design steps (Norton, 2014). In order to be able to generate ideas one most practice creativity, know the discipline in which we need to develop our product, but also the specifics of the sub-discipline.

\subsection{Scope}

The Preparation Phase is explained in this article, thinking that the person or team to perform the task of conceptual design, might use this as a guide to prepare themselves for the next two phases of the method. 


\section{Method}

There are four basic sub-categories that need to be studied to accomplish the preparation phase, prepare for being creative, gather knowledge from the main discipline, gathering knowledge from the specific problem to solve, and planning how we will act during the next phase.

\subsection{Creativity Preparation}

Creativity is not a talent, it is a way of operating (Cleese, 1991).

Neuroscience has taught us using diverse tests, that during a creative process, different parts of the brain are active (Fink et al., 2007), and we also know that there are activities that tend to excite different parts of our brain such as anaerobic exercise, which improves brain, cognition, and cardiovascular fitness (Chapman eta al., 2013). These findings, united with the common knowledge about how creative masters such as Leonardo da Vinci, Maxwell, and even Nikola Tesla were generalists, brings us to the conclusion that having different inputs in the brain, gives a better creative pool from which to extrapolate information and generate new concepts.

As a proposition for creativity preparation, the author proposes increasing the inputs to which the subject that will be confronted to the task of creating is exposed. This activity is of a personal character and to be conducted in a daily basis to have real results. Creating is a highperformance sport, and is to be treated that way. An Olympic athlete must train every day, 8 hours a day, during years to accomplish his physical feat, and in the same way a creative must train during years to have the ability of creating at will.

\subsection{Discipline Background}

Discipline background is mainly achieved from formal education, but it is common that disciplines not related with the actual task of design, such as Industrial, Graphic, Interiors, or Architectural design, has no formal training in the art of design.

The purpose of this study is to help this people to gain understanding of the design methods, and compliment their formal studies.

\subsection{Problem Background}

There are several methodologies that can serve the purpose of gaining knowledge about the problem to be studied. The individual or team intended to perform the design task must choose between which of them best serves their purpose. If a market push product is to be developed, a Quality Function Deployment of QFD methodology (Akao, 2004) is highly suggested for the broad knowledge of the problem. 
For market pull product we will normally have an RFQ (Request for Quotation) which will give us the information needed to have full comprehension of the customer needs.

\subsection{Planning}

Once the team or individual have the three basic preparations to affront the design task, they should plan the approach to the next step, which is technology exploration. It is indeed of great importance to define the keywords to be used in the exploration, which are obtained from the problem background, and state an approximate time to spend in the exploration.

\section{Validation}

An initial validation of this method was made, the participants in this study were 11 women (32.4\%) and 23 men (67.6\%). Thirteen (38.2\%) from design and $21(61.8 \%)$ from engineer. In a $\mathrm{T}$ test of the significance of the difference between the two career groups regarding the sex no difference was obtained: $\mathrm{T}=1.35, \mathrm{p}=.187$.

The creativity test selected was the Creativity Styles Questionnaire-Revised (CSQ-R). The CSQ-R consists of 8 scales and uses a 5 point Likert-type scoring from Strongly-agree (1) to Strongly-disagree (5). Three subscales were selected for this study: Use of techniques; Environmental Control/ Behavioral Self-regulation and Use of the senses. Also, the first 2 items corresponding to the measurement of the global creativity capacity.

In this sample, its Alpha reliability was of $\alpha=.84$, for the hole scale (78 items). Selected sub scales' reliability was: 
Table. 1 CSQ-R Results.

\begin{tabular}{|c|c|c|c|}
\hline Subscales & Objective & $\begin{array}{l}\text { Alpha } \\
\text { reliability } \\
\text { (all items) }\end{array}$ & $\begin{array}{l}\text { Alpha } \\
\text { reliability } \\
\text { (selected } \\
\text { items) }\end{array}$ \\
\hline $\begin{array}{l}\text { Use of techniques } \\
(\alpha=.81)\end{array}$ & $\begin{array}{l}\text { Measure the extent in } \\
\text { which a person uses } \\
\text { specific strategies or } \\
\text { techniques to facilitate } \\
\text { his/her creative work. }\end{array}$ & .68 & $\begin{array}{l}70 \\
\text { (item } 31 \\
\text { out) }\end{array}$ \\
\hline $\begin{array}{l}\text { Environmental Control/ } \\
\text { Behavioral Self-regulation } \\
(\alpha=.83)\end{array}$ & $\begin{array}{l}\text { Measure the extent to } \\
\text { which a person sets up } \\
\text { discriminative stimuli } \\
\text { to facilitate her/his } \\
\text { creative work. }\end{array}$ & .74 & \\
\hline $\begin{array}{l}\text { Use of the senses } \\
(\alpha=76)\end{array}$ & $\begin{array}{l}\text { Measure the extent to } \\
\text { which a person uses } \\
\text { the } 5 \text { senses for } \\
\text { creative work. }\end{array}$ & .77 & \\
\hline Total (40 items) & & .81 & .82 \\
\hline
\end{tabular}

A difference between male, and female was seen in which the men were more strategic while developing their creations, and engineers noted the stimulus that facilitate their work. This can be traduced that the discipline background is very important when approaching a problem, thus we can have a through preparation, if the discipline is very technical, we need individuals that are highly prepared in the discipline, the design method proves a way to make that persons the capability to develop a new product development.

\section{Conclusions}

The preparation phase from the methodology New Product Development; The Nikola Tesla Extrapolation, is to be conducted in different moments of the life of the team or individual to perform the design task. As the creativity preparation shall begin as soon as the person decides that he wants to spend his life enduring in creative efforts, the discipline background is mainly obtained at undergraduate, and graduate studies. For the problem background a specific study must be performed for each design task to develop. 


\section{References}

Akao, Y. (2004). Quality function deployment: integrating customer requirements into product design. Cambridge, MA: Productivity Press.

Bono, E. D. (1978). PO: beyond yes \& no. Harmondsworth, Eng.: Penguin Books.

Chapman S. B, Aslan S, Spence J. S, DeFina LF, Keebler MW, Didehbani N and Lu H (2013) Shorter term aerobic exercise improves brain, cognition, and cardiovascular fitness in aging. Front. Aging Neurosci. 5:75. doi: 10.3389/fnagi.2013.00075

Cleese, J. M. (1991). John Cleese on Creativity. Lecture.

Fink, A., Benedek, M., Grabner, R., Staudt, B., \& Neubauer, A. (2007). Creativity meets neuroscience: Experimental tasks for the neuroscientific study of creative thinking. Methods,42(1), 68-76. doi:10.1016/j.ymeth.2006.12.001

Lockwood, T. (2011). Design thinking integrating innovation, customer experience and brand value. New York, NY: Allworth Press.

Mackinnon, D. W. (1978). In search of human effectiveness. Buffalo: Creative Education Foundation.

Martin, T. C., \& Tesla, N. (1995). The inventions, researches and writings of Nikola Tesla. New York: Barnes \& Noble.

Martinez E. Eduardo (2017). New Product development; the Nikola Tesla extrapolation. 2017 International Conference on Applied System Innovation (ICASI). doi:10.1109/icasi.2017.7988129

Norton, R. L. (2014). Design of machinery: an introduction to synthesis and analysis of mechanisms and machines. New York: McGraw-Hill.

Tesla, N. (2007). The strange life of Nikola Tesla. Place of publication not identified: BN Pub.

Wynn, D. C., Grebici, K., \& Clarkson, P. J. (2011). Modelling the evolution of uncertainty levels during design. International Journal on Interactive Design and Manufacturing (IJIDeM),5(3), 187-202. doi:10.1007/s12008-011-0131-y 